\section{1}

23 Running Title: Bacterial osmoregulated periplasmic polymer CA 94080.

*These authors contributed equally.

analyzed data; and D.M.Z., C.H., and E.H. wrote the paper.

\title{
Structure and function of a novel osmoregulated periplasmic fiber-forming high-molecular-weight carbohydrate of Myxococcus xanthus
}

\author{
Sapeckshita Agrawal ${ }^{\mathrm{a}, 1^{*}}$, Christian Heiss ${ }^{\mathrm{b} *}$, David M. Zuckerman ${ }^{\mathrm{c}, \mathrm{d}}$, Jeffery M. T. So ${ }^{\mathrm{c}}$, Koen \\ Semeijn $^{\mathrm{c}}$, Radnaa Naran ${ }^{\mathrm{b}}$, Parastoo Azadi ${ }^{\mathrm{b}}$, and Egbert Hoiczyk ${ }^{\mathrm{a}, \mathrm{c}, 2}$ \\ ${ }^{\mathrm{a} D e p a r t m e n t ~ o f ~ M o l e c u l a r ~ M i c r o b i o l o g y ~ a n d ~ I m m u n o l o g y, ~ J o h n s ~ H o p k i n s ~ B l o o m b e r g ~}$ \\ School of Public Health, 605 North Wolfe Street, Baltimore, MD 21205, USA. \\ ${ }^{\mathrm{b} C o m p l e x}$ Carbohydrate Research Center, The University of Georgia, 315 Riverbend Rd., \\ Athens, GA 30602.
}

${ }^{\mathrm{c}}$ Department of Molecular Biology and Biotechnology, The Krebs Institute, University of Sheffield, Firth Court, Western Bank, Sheffield, S10 2TN, UK.

${ }^{\mathrm{d}}$ Iona College, 715 North Avenue, New Rochelle, NY 10801.

${ }^{1}$ Present address: NGM Biopharmaceuticals, 333 Oyster Point Blvd., South San Francisco,

${ }^{2}$ To whom correspondence should be addressed. Email: E.Hoiczyk@Sheffield.ac.uk.

Author contributions: S.A., C.H., P.A., and E.H. designed research; S.A., C.H., D.M.Z.,

J.M.T.S., K.S., R.N., and E.H. performed research; D.M.Z., J.T.M.S., C.H., and E.H. 
bioRxiv preprint doi: https://doi.org/10.1101/2020.07.26.208595; this version posted July 26, 2020. The copyright holder for this preprint (which was not certified by peer review) is the author/funder. All rights reserved. No reuse allowed without permission.

Agrawal et al.

Running title: Bacterial osmoregulated periplasmic polymer

1 Keywords: High-molecular-weight carbohydrate, Sugar analysis, Periplasmic glucans,

2 Periplasmic space, Osmoregulation, Osmolyte, Turgor, Spore formation, Myxococcus

3 xanthus.

4 
Agrawal et al. $\quad$ Running title: Bacterial osmoregulated periplasmic polymer

\section{Abstract:}

2 Osmoregulation is of central importance for living cells. In Gram-negative bacteria, 3 strategies for osmoregulation and turgor maintenance in hypotonic environments include the 4 synthesis, accumulation, and modification of periplasmic oligosaccharides. These 5 osmoregulated periplasmic glucans (OPGs, formerly known as membrane-derived 6 oligosaccharides or MDOs) promote water uptake and retention, keeping the cells in an 7 optimal state of hydration. While our understanding of OPG-dependent osmoregulation in a 8 number of model organisms like Escherichia coli is quite detailed, less is known about these 9 processes in bacteria that live in environments characterized by strongly fluctuating 10 osmolarity, such as soil. Here we describe that the soil bacterium Myxococcus xanthus lacks 11 a canonical low-molecular-weight OPG, but instead possesses a novel high-molecular12 weight, fiber-forming polysaccharide. Chemical analysis reveals that this polysaccharide is 13 several thousand kilodaltons in size, composed of a highly branched decasaccharide repeat 14 unit containing mannose, glucose, N-acetylglucosamine, and rhamnose. Physiological experiments indicate that the polysaccharide is osmoregulated thereby functionally replacing

16 the canonical OPG. Moreover, experiments indicate that this high-molecular-weight

17 periplasmic polysaccharide forms a fibrillar meshwork that stabilizes the cell envelope 18 during glycerol spore formation, a process during which the entire peptidoglycan of the cell 19 is degraded and the rod-shaped vegetative cells convert into spherical spores. 
Agrawal et al. Running title: Bacterial osmoregulated periplasmic polymer

\section{Significance:}

2 Osmoprotection is a necessity for every living cell, particularly in an environment with

3 fluctuating osmolarity. In Gram-negative bacteria, low-molecular-weight osmoregulated

4 periplasmic glucans (OPGs) are an important component of the osmotic stress response in

5 hypotonic environments. Here, we describe that the soil bacterium Myxococcus xanthus does

6 not possess such an OPG but instead accumulates a novel high-molecular-weight fiber-

7 forming polysaccharide in the periplasm in response to hypotonic conditions. This polymer

8 is important for osmoprotection of the cells and plays a key role in the stabilization of the

9 cell envelope during the conversion of rod-shaped vegetative cells into spherical spores.

10 These results indicate that bacteria may use non-OPG carbohydrates for osmoprotection and

11 cell wall stabilization during processes like cellular differentiation.

12

13

14 
Agrawal et al. Running title: Bacterial osmoregulated periplasmic polymer

\section{Introduction:}

2 Maintaining a stable cell turgor is essential for bacteria to sustain rigidity, control transport

3 processes and solute concentrations, and allow for normal growth (Wood, 2011). Events that

4 disturb this balance induce physiological responses that allow cells to re-establish their

5 turgor and prevent or minimize potentially harmful consequences. In all proteobacteria

6 examined, low environmental osmolarity triggers the synthesis and accumulation of

7 osmoregulated periplasmic glucans (OPGs), polyglucose oligosaccharides that are an

8 important component of the periplasm (Schulman and Kennedy, 1979; Ehrmann, 2006).

9 OPGs were first discovered in the culture filtrates of Agrobacterium tumefaciens and

10 initially mistaken as low-molecular-weight (MW) exopolysaccharides (EPSs) (McIntire et

11 al., 1942). With the subsequent discovery of the "membrane-derived oligosaccharides"

12 (MDOs) in Escherichia coli, a second group of OPGs was identified (Van Golde et al.,

13 1973), and it was eventually recognized that both the cyclic glucans of Agrobacterium and

14 the linear glucans of Escherichia are periplasmic osmoprotective carbohydrates (Kennedy,

15 1982; Miller et al., 1986). Since then, research has shown that all characterized OPGs share a

16 number of core features (reviewed in Bohin, 2000 and Lee at al., 2009 and references

17 therein). They all are short, 5-40 glucose unit-long oligosaccharides that are mostly linked

18 via $\beta$-glycosidic bonds and synthesized in the periplasm in response to low environmental

19 osmolarity. Based on their size and the linkage of their polyglucan backbone, OPGs have

20 been classified into four different families. Family I, which is found in Escherichia, Erwinia,

21 and Pseudomonas species is heterogeneous in length ranging from 5-28 glycosyl residues

22 that form a $\beta$-1,2-linked linear backbone carrying $\beta$-1,6-linked branches of glycosyl units.

23 Family II, which has been described in Agrobacterium, Sinorhizobium, Mesorhizobium, and 
Agrawal et al. Running title: Bacterial osmoregulated periplasmic polymer

1 Brucella species, form cyclic structures by $\beta-1,2-$ linkages of glycans that are 17-40 glycosyl

2 residues long. Like family II, family III OPGs are cyclic, but in contrast they are shorter,

3 only 10-13 glycosyl units long, and possess $\beta-1,3$ and $\beta-1,6$ glycosidic bonds. OPGs of this

4 family have so far been found in Bradyrhizobium, Azorhizobium, and Azospirillum species.

5 Finally, family IV OPGs, described in Xanthomonas, Ralstonia, and Rhodobacter species,

6 are cyclic, 13-18 glycosyl unit-long oligosaccharides that contain a $\beta$-1,2-linkage backbone

7 with one additional single $\alpha-1,6$-linkage. OPGs of all four families can also contain

8 additional non-sugar substituents. Two types of such substituents have been identified:

9 molecules which derive from the turnover of phospholipids such as phosphoethanolamine,

10 phosphoglycerol, and phosphocholine, and substituents that are products of the cellular

11 metabolism like acetyl, succinyl, and methylmalonyl residues (Bohin, 2000; Lee et al.,

12 2009). Both the nature and the degree of substitution can vary within a species, reflecting the

13 growth rate of the bacteria as well as environmental conditions. For example, the family II

14 type cyclic OPG from Sinorhizobium meliloti can be converted from a neutral molecule to a

15 highly charged anionic oligomer, a conversion that is more rapid and complete in

16 exponentially growing cells than in stationary cultures (Geiger et al., 1991). As some OPGs

17 are never substituted, the overall role of substitutions for the physiological function of OPGs

18 is not well understood. Although there is a great deal of diversity in the composition of

19 OPGs, it is generally accepted that all OPGs play a major role in osmoprotection by keeping

20 the periplasms of cells hydrated (Kennedy, 1982; Miller et al., 1986). Beyond this

21 osmoprotective function, OPGs have been proposed to play roles in a few well studied

22 bacteria in virulence, host colonization, cell signaling, protein folding, and envelope

23 structure (reviewed in Bontemps-Gallo at al. 2017). While OPGs have been studied in many 
Agrawal et al. Running title: Bacterial osmoregulated periplasmic polymer

$1 \alpha-, \beta$-, and $\gamma$-proteobacteria, in $\varepsilon$-proteobacteria so far only functional analogs, called OPG-

2 like oligosaccharides, have been identified, and no information exists regarding OPGs in $\xi$ -

3 and $\delta$-proteobacteria (Bontemps-Gallo and Lacroix, 2015).

4 Myxococcus xanthus is a common soil-dwelling myxobacterium of the $\delta$-proteobacteria class

5 that is highly social and forms swarms that cooperatively prey on other bacteria (Berleman

6 and Kirby, 2009). Possessing one of the most complex prokaryotic genomes (Goldman et al.,

7 2006), these bacteria perform surface motility (Chang at al. 2016; Faure et al., 2016) and,

8 upon starvation, initiate a complex developmental program during which vegetative cells

9 aggregate and a subset of cells undergo a rod-to-sphere transition to form spores within a

10 fruiting body (Zusman et al., 2007). Like all soil organisms, M. xanthus has developed

11 adaptations that help the cells cope with their frequently fluctuating environment. One

12 behavioral strategy is developmental differentiation that allows the bacteria to match cell

13 density with available food resources (Berleman et al., 2008). Another strategy is phase

14 switching, a genetic program that generates phenotypic variation through the expression of

15 different sets of genes in subpopulations of bacteria (Furusawa et al., 2011; Higgs et al.,

16 2014). This variation provides a selective advantage because members of a subpopulation

17 will be better adapted to survive under certain environmental conditions (Higgs et al., 2014;

18 Dziewanoswka et al., 2014). While both strategies, differentiation and phase switching, work

19 on the population level, much less is known about how individual cells physiologically cope

20 with changes in the environment such as water availability. Here, we describe that $M$.

21 xanthus lacks a canonical OPG under standard laboratory growth conditions, but instead

22 synthesizes a periplasmic high-MW carbohydrate that appears to protect the cells during

23 developmental cell-to-spore transition. This novel carbohydrate is many hundred times 
Agrawal et al. Running title: Bacterial osmoregulated periplasmic polymer

1 larger in size than any previously described OPGs, and fibers are so large that they are

2 visible by electron microscopy. Moreover, the polymer also differs chemically from known

3 OPGs, containing several sugars other than glucose. Despite these differences, however, it

4 performs a physiological function comparable to OPGs, as its synthesis is osmoregulated.

5 Taken together, these data indicate that bacteria living in environments characterized by

6 wide ranging osmotic fluxes may use unusual polymeric high-MW OPGs that have so far

7 been overlooked as they are not liberated upon classic OPG isolation procedures.

\section{Results}

10 Myxococcus xanthus synthesizes a high-MW carbohydrate. During attempts to isolate

11 pili, we noted that when $M$. xanthus cells were subjected to high shear forces, but not

12 broken, the supernatant of the cell suspension became highly viscous (Fig. 1A). Since efforts

13 to lower this viscosity through digestion with DNase failed, we concluded that a non-nucleic

14 acid polymer had been released; an interpretation that was supported using the carbohydrate-

15 specific anthrone test (Seifter et al., 1950). Taking advantage of its high MW (Fig. 1B), we

16 developed a purification scheme for this carbohydrate (for details see Materials and

17 Methods). To exclude the possibility that this polymer was part of the exopolysaccharide

18 (EPS) matrix of M. xanthus, we repeated the isolations using liquid-grown cells of the EPS-

19 deficient $\triangle$ difE strain (Black and Yang, 2004; Lu et al., 2005). Electron microscopy

20 confirmed that the isolated carbohydrate in both cases was a high-MW polymer formed by

21 ca. $4 \mathrm{~nm}$ wide filaments that, like cellulose fibers (Hiagler, 1985; Jakob et al., 1995),

22 aggregated into thicker bundles up to $40 \mathrm{~nm}$ wide (Fig. 1C). Initial attempts to further purify

23 the polymer using a gel filtration column (molecular cutoff $500 \mathrm{kDa}$ ) failed because the 
Agrawal et al. Running title: Bacterial osmoregulated periplasmic polymer

1 native molecule eluted in the void volume, consistent with a molecule of very large size.

2 Upon partial hydrolysis, we could reproducibly isolate a ca. $400 \mathrm{kDa}$ large fragment suitable

3 for chemical analyses (Fig. 1D; and below).

4

5 The isolated polymer is located in the periplasm of the cell, which lacks a canonical

6 OPG under standard culture conditions. Following the observation that we could recover

7 this carbohydrate from the EPS-deficient $\triangle$ difE strain, strongly suggesting that the material

8 was not part of the EPS matrix, we next attempted to more specifically determine its cellular

9 localization. Polyclonal antibody raised against the purified polymer preferentially labeled

10 the cell envelopes of $\triangle$ difE cells, indicating that the polymer is located either on the surface

11 of the outer membrane or in the periplasm (Fig. 2A). Since our initial observation indicated

12 that the polymer is only released when the cells are subjected to high shear, we next tested

13 various treatments for their ability to release the material (Fig. 2B). By far the most effective

14 treatment was osmotic shock, a procedure that specifically releases the periplasmic content

15 of Gram-negative bacteria (Nossal and Heppel, 1966). Less effective was agitation in a

16 blender, while shaking or washing of the cells with salt solutions, methods usually used for

17 EPS isolation, released only negligible amounts of polymer. Together these results indicated

18 that the outer membrane had to be physically ruptured to release the material, an observation

19 that supported the idea that the polymer is located in the periplasm. To further corroborate

20 this conclusion, we next established that the polymer was released under the same conditions

21 as the well-established periplasmic marker, alkaline phosphatase (Nossal and Heppel, 1966;

22 Fig. 2C, dark grey bars), and that during these extractions the cytoplasmic membrane was

23 not breached, and only negligible amounts of cytoplasmic content released, using the 
Agrawal et al. Running title: Bacterial osmoregulated periplasmic polymer

1 cytoplasmic protein EncA as a marker (McHugh et al., 2014; Fig. 2D). Notable, the

2 measured alkaline phosphatase data match closely data reported in an earlier publication

3 (Rodriguez-Soto and Kaiser, 1997; Fig. 2C, light grey bars). In summary, these results

4 demonstrated that the polymer is periplasmic and only released using methods and

5 conditions that liberate known periplasmic markers.

6 Since OPGs have commonly been found in the periplasm of other Gram-negative bacteria

7 (Bontemps-Gallo et al., 2017), we next tested whether M. xanthus also contained a canonical

8 low-molecular-weight OPG. M. xanthus wt and $\Delta$ difE cells were grown in both liquid culture

9 and on agar, collected, and treated with 5\% trichloroacetic acid, a standard method for

10 isolating OPGs. We failed to detect the release of any OPGs, indicating that under standard

11 growth conditions, the cells appear to lack this periplasmic component.

12

13 Chemical analysis shows that the M. xanthus polymer is highly branched and formed

14 by a complex decasaccharide repeat unit. Using glycosyl composition analysis of the

15 dialyzed $M$. xanthus periplasmic high-MW carbohydrate (MXP), we identified the

16 monosaccharides constituting the polymer as mannose, glucose, $\mathrm{N}$-acetylglucosamine, and

17 rhamnose. We performed a linkage analysis of MXP using the experimental sequence of

18 permethylation, hydrolysis, reduction, and acetylation (Pettolino et al., 2012), and detected

19 the resulting partially methylated alditol acetates (PMAAs) by gas chromatography with

20 mass spectrometric detection (GC-MS). We found PMAAs corresponding to the following

21 major linkages (Table S1): terminal, 4-linked, and 2,3-linked rhamnose (Rha), terminal, 3-

22 linked, and 2,3,4-linked glucose (Glc), 3-linked and 2,3-linked mannose (Man), and terminal

23 and 3-linked N-acetylglucosamine (GlcNAc). Aqueous solutions of the native MXP were 
Agrawal et al. Running title: Bacterial osmoregulated periplasmic polymer

1 too viscous to allow acquisition of useful NMR spectra. For this reason, we treated the MXP

2 with dilute acid to obtain a more tractable material, which was isolated by semi-preparative

3 size exclusion high performance liquid chromatography (SEC-HPLC). The resulting size-

4 reduced polysaccharide (MXP-A) had an average molecular weight of $400 \mathrm{kDa}$ and was

5 much more amenable to solution-state NMR analysis. We acquired a series of 1- and 2-

6 dimensional NMR spectra of MXP-A (Fig. S3) and found that the spectra were remarkably

7 complex, showing more than 25 anomeric signals. To simplify the structure further, we

8 performed a Smith degradation on MXP-A (Perlin, 2006; MacLean and Perry, 2010). We

9 separated the resulting products by SEC-HPLC and detected both polymeric material and

10 released monosaccharides, collecting the tail end of the polymeric peak for further

11 characterization. Linkage analysis of the Smith degraded polymer (MXP-AS) (Table S1)

12 showed that the 2,3,4-Glc and 3-GlcNAc linkages were still present, while the 2,3-Man, the

13 2,3-Rha, and the 4-Rha linkages had disappeared. Although terminal residues do not survive

14 the Smith degradation, among the terminal sugars in the original material, only terminal

15 GlcNAc disappeared in the linkage analysis of MXP-AS. We interpret this to mean that new

16 terminal Glc and Rha residues were created from the previous 2,3-Rha and 3-Glc. The

17 proton NMR spectrum showed 5 major anomeric signals, 2 prominent signals near 4.2 ppm,

18 consistent with the H-2 proton of Man or Rha, a complex carbohydrate bulk region, an N-

19 acetyl signal near 2 ppm, and a Rha H-6 signal near 1.3 ppm. Following the connectivities in

20 the proton-proton Correlation Spectroscopy (COSY) and Total Correlation Spectroscopy

21 (TOCSY) spectra and reading carbon chemical shifts from the proton-carbon Heteronuclear

22 Single Quantum Correlation (HSQC) spectrum (Fig. S4) (Duus et al., 2000) allowed us to

23 assign nearly all of the chemical shifts of the 5 major monosaccharide residues present in the 
Agrawal et al. Running title: Bacterial osmoregulated periplasmic polymer

1 MXP-AS sample (Table S2) and to identify sugar type and anomeric configuration. Thus,

2 the 5 residues were identified as 2,3,4- $\alpha$-Glc (Residue A), 3- $\alpha$-Man (Residue B), $\beta$-3-

3 GlcNAc (Residue C), $\alpha$-Rha (Residue D), and $\alpha$-Glc (Residue E), all in pyranose form.

4 Proton-proton Nuclear Overhauser Effect Spectroscopy (NOESY) and proton-carbon

5 Heteronuclear Multiple Bond Correlation (HMBC) spectra (Fig. S4) were used to determine

6 the connectivities between these residues and to define the sequence of MXP-AS. NOESY

7 cross peaks were observed between $\mathrm{H}-1$ of $\mathbf{A}$ and $\mathrm{H}-3$ of $\mathbf{B}, \mathrm{H}-1$ of $\mathbf{B}$ and $\mathrm{H}-3$ of $\mathbf{C}, \mathrm{H}-1$ of $\mathbf{D}$

8 and $\mathrm{H}-4$ of $\mathbf{A}$, and $\mathrm{H}-1$ of $\mathbf{E}$ and $\mathrm{H}-2$ of $\mathbf{A}$. Only $\mathrm{H}-1$ of $\mathbf{C}$ did not show any inter-residue

9 NOE cross peak. However, the HMBC spectrum revealed the connectivity of Residue $\mathbf{C}$ by

10 displaying a cross peak between its $\mathrm{H}-1$ and C-3 of Residue A. The HMBC spectrum also

11 confirmed the connectivities of the other residues. Taken together, these data lead to the

12 conclusion that MXP-AS has a pentasaccharide repeating unit consisting of a [3- $\beta$-GlcNAc-

13 1-3- $\alpha$-Glc-1-3- $\alpha$-Man-1-] trisaccharide backbone, decorated with $\alpha$-Glc on O-2 and $\alpha$-Rha on

14 O-4 of the backbone Glc residue (Fig 3A). All residues were in pyranose form (omitted in

15 the structure drawing for simplicity's sake). Having thus determined the core structure of

16 MXP, we set out to establish the location of the residues that were removed during the Smith

17 degradation. Comparing the linkage data of MXP and MXP-AS, we were able to determine

18 the positions that were glycosylated in the native polysaccharide (Fig. 3B). Next, we

19 identified the sugars in these positions by re-examining the NMR spectra of MXP-A. From

20 the linkage data, we knew that the missing residues were terminal Rha, terminal Glc, and

21 terminal GlcNAc, as well as 4-linked Rha. Although we could not identify all the

22 monosaccharide residues present in the NMR spectra of MXP-A (Fig. S5), we were able to

23 partially assign most of the residues that were needed to complete the structure elucidation. 
Agrawal et al. Running title: Bacterial osmoregulated periplasmic polymer

1 It was beneficial for this process that the linkages involved mostly O-2 and O-3, i.e.

2 positions that are relatively close to the anomeric center, so that only some of the protons

3 and carbons in each residue had to be assigned in order to establish connectivities. Table S3

4 shows the assignments that were thus obtained. The 2,3,4- $\alpha$-Glc residue was readily assigned

5 because it had similar chemical shifts to its counterpart in MXP-AS. The chemical shifts of

6 Man and Rha residues are very similar, in that both have downfield H-2 chemical shifts, and

7 we found two residues with $\mathrm{H}-2$ chemical shifts greater than $4 \mathrm{ppm}$. However, only one of

8 the H-2 protons was correlated in the TOCSY spectrum with the H-6 methyl group of Rha,

9 thus the other residue was identified as Man. Both of these residues were in the $\alpha$ -

10 configuration, as evidenced by the downfield chemical shift of their anomeric protons. The

11 Man residue had downfield chemical shifts for C-2 and C-3, showing glycosylation on O-2

12 and O-3. Although from the linkage analysis we expected to find 2,3-Rha in the NMR

13 spectra, the Rha residue showed only a downfield displacement of C-3, whereas C-2 was

14 more typical of an unsubstituted position. None of the other spin systems in the spectra of

15 MXP-A were consistent with 2,3- $\alpha$ - or $2,3-\beta$-Rha. Therefore, we concluded that the

16 substituent that had originally been attached to O-2 of this Rha residue was lost during the

17 initial mild acid hydrolysis. We were further able to identify and partially assign two

18 terminal $\alpha$-GlcNAc residues, a 3-linked $\beta$-GlcNAc residue, a 3 -linked $\alpha$-Glc residue, and a

19 terminal $\beta$-Glc residue. NOE and HMBC correlations (Fig. S5) clearly indicated linkage of

20 the $\beta$-Glc residue to O-2 of $\alpha$-Man, establishing the location of this terminal residue. An

21 NOE contact proved that the attachment site of the terminal $\alpha$-GlcNAc residue $\mathbf{G}$ was on O-

223 of Residue E. The connectivity of the other terminal $\alpha$-GlcNAc (Residue F) was more

23 difficult to discern because its anomeric proton was correlated to a signal that could belong 
Agrawal et al. Running title: Bacterial osmoregulated periplasmic polymer

1 to either $\mathrm{H} / \mathrm{C}-3$ of $3-\alpha-\mathrm{Rha}$ or $3-\beta-\mathrm{GlcNAc}$, as these two signals resonated at the same

2 position in both proton and carbon dimensions. However, the $\alpha$-GlcNAc residue could not be

3 attached to the 3- $\beta$-GlcNAc, because Smith degradation would have liberated a terminal

4 GlcNAc, but none was found in the linkage analysis of MXP-AS. Hence, the $\alpha$-GlcNAc $\mathbf{F}$ is

5 attached to O-3 of 3- $\alpha$-Rha (Residue D). The location of the terminal and 4-linked Rha

6 residues was determined by their absence in the NMR spectra. None of the spin systems

7 detected in the spectra were consistent with either of these linkages in $\alpha$ - or $\beta$-form.

8 Apparently these two residues constituted the side chain that was attached to O-2 of Residue

9 D in MXP, but which was lost during acid hydrolysis. Thus, we conclude that a Rha-1-4-Rha

10 disaccharide side chain is attached to O-2 of 2,3- $\alpha$-Rha in MXP before acid hydrolysis.

11 Combining all these results, the proposed structures of MXP and MXP-A are pictured in Fig.

$123 \mathrm{C}$.

14 The synthesis of the periplasmic polymer is osmoregulated. Low-MW OPGs or OPG-like

15 oligosaccharides are the only currently described periplasmic carbohydrates of Gram-

16 negative bacteria; in virtually all cases their synthesis is osmoregulated (Lee et al., 2009;

17 Bontemps-Gallo and Lacroix, 2015). Therefore, we next examined the osmoregulation of the

18 periplasmic polymer. Since $M$. xanthus is grown in CTT medium (85 mOsm), our initial

19 isolations demonstrated that the polymer was abundantly synthesized at low osmolarity.

20 However, testing the high osmolarity scenario using liquid media was challenging, as the

21 cells both do not tolerate the addition of salt and are strictly aerobic, and therefore sensitive

22 to changes in oxygen availability caused by increasing viscosity through the addition of

23 outer membrane-impermeable polymers such as polyethylene glycol (PEG). Therefore, we 
Agrawal et al. Running title: Bacterial osmoregulated periplasmic polymer

1 performed these experiments using cells grown on trays of solid CTT medium containing

2 various concentrations of PEG (Chang et al., 2007) and gelrite as the solidifying agent, as

3 agar does not solidify in the presence of PEG (Shungu et al., 1983). After confirming that

4 replacing agar with gelrite had no effect on the synthesis of the polymer at low osmolarity,

5 we repeated our isolations from cells grown at intermediate, $8 \%(0.5 \mathrm{MPa})$ and high, $16 \%$

6 (1 MPa) PEG concentrations (Chang et al., 2007). After harvesting the cells, we monitored

7 the abundance of the polymer by examining both the crude fraction containing the polymer

8 (Fig. 4A) and the purified $400 \mathrm{kDa}$ large fragment (Fig. 4B). We were able to recover less of

9 the periplasmic polymer at intermediate osmolarity (5\% at $8 \%$ PEG) and none whatsoever at

10 high osmolarity (16\% PEG; Fig. 4). Of note, these data demonstrate that the polymer,

11 although chemically very different from OPGs, physiologically phenocopies them including

12 the osmoregulation of their synthesis.

14 M. xanthus encodes OpgG and OpgH homologs. Although we were unable to isolate a 15 canonical OPG, we searched the genome of M. xanthus for the presence of genes potentially 16 involved in the synthesis of periplasmic glucans. Homologs of two core genes necessary for 17 canonical OPG synthesis in most bacteria, opgG (mxan_2385) and opgH (mxan_2383)

18 (Bontemps-Gallo et al., 2017), are present in M. xanthus. The primary amino acid sequences

19 of OpgG and $\mathrm{H}$ in various species were compared. Whereas OpgG is highly conserved 20 throughout its entire sequence among various bacteria (Fig. S1), OpgH sequences show a 21 higher degree of variation, particularly at their N- and C-termini (Fig. S2). In M. xanthus, for example, the N-terminus is 124 aa shorter than in E. coli. We next attempted to delete these

23 genes to test whether they are involved in the synthesis of the periplasmic high-molecular- 
Agrawal et al. Running title: Bacterial osmoregulated periplasmic polymer

1 weight carbohydrate. Repeated attempts at deleting opgG failed, indicating that this gene

2 may be essential in $M$. xanthus grown under standard conditions. Efforts to delete opgH

3 were similarly unsuccessful. As we were unable to delete these genes, and as no simple

4 correlation between OPG protein sequences and synthesized polymers has been identified

5 (Bontemps-Gallo et al., 2017), we are currently unable to assess whether OpgG and $\mathrm{H}$ in $M$.

6 xanthus are involved in the synthesis of the high-molecular-weight periplasmic

7 carbohydrate.

9 The osmoregulated periplasmic polymer appears to protect and stabilize cells during

10 the rod-to-sphere conversion of glycerol spore formation. In addition to environmental

11 changes in osmolarity, vegetative cells of $M$. xanthus degrade their peptidoglycan during

12 rod-to-spore morphogenesis (Bui et al., 2009; Higgs et al., 2014) and become highly

13 sensitive to peptidoglycan-targeting antibiotics (White et al., 1968; Jones et al., 1981).

14 Consistent with the osmoregulation of MXP we observed and known osmoprotection

15 conferred by OPGs, we hypothesized that the fiber-forming periplasmic polymer may also

16 function to mechanically stabilize the cells during the cell wall remodeling process during

17 sporulation. To test this hypothesis, we grew vegetative cells in conditions under which they

18 produce either ample (low osmolarity CTT) or virtually no polymer (high osmolarity

19 CTT+16\% PEG) and tested the cell's ability to successfully form spores upon glycerol

20 induction (Dworkin and Gibson, 1964). Although we cannot completely rule out that the

21 different growth regimens affect other processes that influence spore formation, the results

22 indicated that cells possessing the periplasmic polymer completely converted to spores

23 within $2 \mathrm{~h}$, while never more than ca. $40 \%$ of the cells lacking the polymer converted after 
Agrawal et al. Running title: Bacterial osmoregulated periplasmic polymer

$14 \mathrm{~h}$ or longer of stimulation, moreover, many of these cells failed to become completely

2 spherical (Fig. 5). Therefore, polymer-lacking cells appear to be highly impaired in their

3 ability to form spores both with respect of the speed as well as the completeness of the

4 conversion. In summary, these data support the hypotheses that the fiber-forming polymer is

5 important for osmoprotection, and moreover forms a periplasmic fibrillar meshwork that

6 mechanically supports the cell envelope during rod-to-spore morphogenesis. In the latter

7 case, it would support the mechanical robustness of the cell during the time before the newly

8 synthesized spore coat replaces the degraded peptidoglycan layer, meaning that a complete

9 conversion process would only be possible in the presence of the polymer (Bui et al., 2009;

10 Higgs et al., 2014).

\section{Discussion:}

14 OPGs or OPG-like oligosaccharides are linear or cyclic 5-40 glucose molecule-long 15 compounds that have been found in the periplasms of $\alpha_{-}, \beta-, \gamma-$, and $\varepsilon$-proteobacteria and 16 that are an important part of the cell's response to changes in environmental osmolarity 17 (Bontemps-Gallo and Lacroix, 2015; Bontemps-Gallo at al., 2017). Here, we show that $M$. 18 xanthus, a $\delta$-proteobacterium, appears to lack a canonical OPG. Instead, the bacterium 19 synthesizes a high-MW fiber-forming periplasmic carbohydrate that is chemically distinct 20 from any known OPGs. First, it is substantially larger than canonical OPGs. Although we 21 were not able to determine its native weight, we reason that it must be several thousand 22 kilodaltons because the non-hydrolyzed polymer forms microscopically-visible, micrometer23 long filaments and limited acid hydrolysis released a fragment of about $400 \mathrm{kDa}$. This is in 
Agrawal et al. Running title: Bacterial osmoregulated periplasmic polymer

1 strong contrast to the MW of canonical OPGs, which are usually smaller than $8 \mathrm{kDa}$ (Bohin,

2 2000; Lee et al., 2009). Secondly, while all OPGs are polyglucans, this polymer contains

3 three additional monosaccharides beside glucose, namely mannose, $\mathrm{N}$-acetylglucosamine,

4 and rhamnose. In addition, its decasaccharide repeat unit contains mostly $\alpha$-glycosidic

5 bonds, which differs from the $\beta$-glycosidic bonds dominating OPGs. Finally, OPGs are often

6 modified with negatively charged groups resulting in a strong anionic character of these

7 molecules. In contrast, no such substituents were detected in the polymer despite extensive

8 analyses, indicating that this molecule appears to be neutral under all tested growth

9 conditions. The only two aspects in which the polymer resembles canonical OPGs is its

10 periplasmic location and the fact that its synthesis is osmoregulated, indicating that it may

11 physiologically function like OPG. Intriguingly, bioinformatics identified in M. xanthus two

12 core genes, opgG and opgH responsible for the synthesis of canonical OPGs in other

13 bacteria. Repeated attempts to delete these genes failed, indicating that they appear to be

14 essential under normal growth conditions. Therefore, we were unable to directly test their

15 involvement in osmotolerance or MXP synthesis. In these other bacteria, no sequence-based

16 correlation between opg genes and the chemistry of their products has been found, therefore

17 we are unable to conclude that they do synthesize MXP. Consequentially, two scenarios

18 could be possible: either opgG and $\mathrm{opg} H$ are involved in the synthesis of the high-MW

19 periplasmic polymer, further indicating that correlation between opg genes and their

20 products is virtually impossible, or the bacterium produces a canonical OPG that we were

21 unable to detect. We do not currently have experimental evidence to support either of these

22 hypotheses. However, based on the fact that the chemical composition and structure of MXP 
Agrawal et al. Running title: Bacterial osmoregulated periplasmic polymer

1 is so different from canonical OPGs, we consider it more likely that not yet identified

2 glysosyltransferases are responsible for the synthesis of this polymer.

3 Together these observations strongly suggest that one of the main functions of the polymer is

4 osmoprotection through the facilitation of a hydrated periplasmic space. As has been

5 proposed for OPGs, this does not exclude the possibility that the polymer could also play

6 other non-osmoregulated roles such as providing a cellular pool of monosaccharides,

7 controlling periplasmic crowding, interacting with enzymes, influencing the solubility of

8 compounds, or performing structural roles (Lee et al., 2009; Bontemps-Gallo et al., 2017).

9 Because all of these functions can be accomplished by canonical OPGs, it raises the question

10 why the periplasmic carbohydrate of $M$. xanthus is so different. Since no other $\delta$ -

11 proteobacterium has so far been characterized with respect to its $\mathrm{OPG}$, it is conceivable that

$12 \delta$-proteobacteria, or more specifically, myxobacteria, generally possess larger, more

13 structurally complex OPGs. This could be explained by the evolutionary history, as the

14 branch point between the $\delta$-proteobacteria and the remaining proteobacteria is ancient,

15 suggesting a distant genetic relationship (Emerson et al., 2007). However, we consider it

16 more likely that this polymer in M. xanthus fulfills a function that is linked to the particular

17 life cycle of this organism. M. xanthus, like other myxobacteria, is characterized by its

18 unique ability to undergo developmental differentiation, a process during which starving

19 cells coalesce into fruiting bodies, and eventually differentiate into spores (Zusman et al.,

20 2007). While spore formation exists in other bacteria, the process in M. xanthus differs

21 fundamentally from the analogous event in endospore-forming bacteria such as Bacillus

22 subtilis (McKenney et al., 2013) in that the entire vegetative cell converts into a spherical

23 spore without an initial asymmetric septation event (Higgins and Dworkin, 2012; Higgs et 
Agrawal et al. Running title: Bacterial osmoregulated periplasmic polymer

1 al., 2014). During this conversion process, the entire peptidoglycan of the vegetative cell is

2 actively rearranged and finally completely degraded (Bui et al., 2009) while the cell

3 simultaneously forms a spore coat that functionally replaces the peptidoglycan layer (Higgs

4 et al., 2014; Holkenbrink et al., 2014). Consequently, the cells are particularly vulnerable to

5 peptidoglycan-targeting antibiotics or to mechanical or osmotic stress during this rod-to-

6 spore morphogenesis (White et al., 1968; Jones et al., 1981). As our experiments suggest,

7 cells that possess the high-MW polymer can convert rapidly and completely ( $100 \%$ within

$82 \mathrm{~h}$ ) while those lacking the molecule are highly impaired in their ability to convert (with not

9 more than $40 \%$ undergoing morphogenesis even after $4 \mathrm{~h}$ ). The simplest explanation of this

10 observation is that the fibrils of the polymer form a periplasmic meshwork that mechanically

11 helps stabilize the cell envelope during the re-organization. This idea points to a highly

12 specific function in $M$. xanthus suggesting that such large polymers may only be found in

13 other spore-forming myxobacteria. However, since such polymers have not been identified

14 in other species this interpretation is speculative; indeed, since the standard OPG isolation

15 procedure using TCA does not release the polymer from M. xanthus, similar high-MW

16 polymers may be produced by other bacteria but have been overlooked. For example, two

17 studied bacteria, Brucella Sp. and Sinorhizobium meliloti strain GR4, possess OPGs that are

18 not osmoregulated (Miller and Wood, 1996), which may point to the possibility that they

19 possess other periplasmic molecules that are osmoregulated and involved in osmoprotection.

20 Moreover, since high-MW carbohydrates are usually per definition classified as EPS, it may

21 be that such polymers have already been discovered but misinterpreted as extracellular

22 molecules. Ironically, such misidentification would mirror the initial discovery of OPGs,

23 which were isolated from culture supernatants of A. tumefaciens and identified as crown gall 
Agrawal et al. Running title: Bacterial osmoregulated periplasmic polymer

1 polysaccharides and initially thought to be a specific sub-fraction of EPS (McIntire et al.,

2 1942), before later studies revealed their periplasmic nature (Van Golde et al., 1973;

3 Schulman and Kennedy, 1979). The discovery of the periplasmic polymer raises a new

4 question, namely, the fate of the polymer after the conversion of the rods into spores. It will

5 need to be resolved whether the polymer is kept in spores as part of the multilayered spore

6 coat (Higgs et al., 2014; Holkenbrink et al., 2014) or whether it is enzymatically degraded

7 and potentially used to synthesize spore coat material.

8 While the roles of the newly discovered periplasmic polymer in osmoregulation and cell

9 envelope stabilization appear apparent, it likely influences additional cell envelope-related

10 processes. One such process is A-motility in M. xanthus, a form of surface-associated

11 locomotion that relies on large-scale interaction between the bacterial cell surface and the

12 underlying substrate (Nan et al., 2014; Islam and Mignot, 2015). Although the precise

13 molecular mechanism for this motility is still debated, it is clear that the cell envelope plays

14 a major role. According to one model, the focal adhesion model (Mignot et al., 2007),

15 motility is driven by the movement of motor complexes that reside at the cytoplasmic

16 membrane and move along cytoskeletal tracks. As these motor complexes simultaneously

17 bind to the extracellular substrate, they push the cells forward while moving backwards on

18 the tracks (Faure et al., 2016). It has been noted that the presence of the peptidoglycan

19 sacculus would potentially hinder the movements of such trans-envelope complexes (Nan et

20 al., 2014); we suggest that the fibrillary periplasmic meshwork reported here may be an

21 additional obstacle. In addition, this meshwork may influence important aspects of another

22 A-motility model, the helical rotor model (Nan et al., 2010; Nan, 2017). Here, cytoplasmic

23 cargo protein complexes are proposed to move backwards on a helically arranged 
Agrawal et al. Running title: Bacterial osmoregulated periplasmic polymer

1 cytoskeleton generating trans-envelope wave-like deformations that push the cell forward.

2 An important constraint of this model is the ability of these protein complexes to generate

3 waves with an amplitude large enough to be effective outside the cell. While it is difficult to

4 judge how the periplasmic polymer would influence the transmission of such waves, the

5 contribution of such structural feature to the envelope must be considered.

6 Another process to which the polymer could contribute is cellular flexibility. Although

7 myxobacteria are physiologically like any other Gram-negative bacteria, they are extremely

8 flexible, a characteristic they share i.e. with flexibacteria (Burchard, 1981; 1982). In contrast

9 to i.e. E. coli, this allows M. xanthus to bend, turn, and twist, behaviors that have been

10 exploited to examine their motility (Wolgemuth, 2005). No plausible ultrastructural

11 explanation has been presented as to how the cells are able to bend at such great angles

12 without snapping and breaking. The conventional view holds that the peptidoglycan is the

13 mechanical structure that shapes the cells. However, since the periplasmic fibrillar

14 meshwork certainly influences the overall mechanical properties of the cell envelope, we

15 consider that this gel-like meshwork may behave like a hydroskeleton that can redistribute

16 within the periplasm to accommodate strong physical deformations, or by doing so initiates

17 rapid flexing of the cell body.

18 In addition, the meshwork could be involved in the strong tendency of M. xanthus cells to

19 extrude outer membrane vesicles (Palsdottir et al., 2009). Although vesicle formation has

20 been observed for every Gram-negative bacterial species (Kulp and Kuehn, 2010),

21 myxobacteria stand out for the sheer amount of these structures often resulting in the

22 formation of vesicle chains or tubes (Palsdottir et al., 2009; Berleman and Auer, 2013; Wei

23 et al., 2014). Vesicle formation together with membrane fusions are at the basis of many 
Agrawal et al. Running title: Bacterial osmoregulated periplasmic polymer

1 aspects of myxobacterial multicellularity such as surface protein and LPS exchange (Pathak

2 et al., 2012, Ducret et al., 2013; Wei et al., 2014; Vasallo et al., 2015), cell-to-cell signaling

3 (Stevens and Søgaard-Andersen, 2005) and kin selection (Velicer and Vos, 2009; Vasallo et

4 al., 2017). The presence of an osmotically active periplasmic carbohydrate could

5 conceivably play a role in generating some of the force necessary to generate these important

6 surface structures.

7 Finally, the periplasmic fibrillar OPG meshwork could certainly influence cell division as it

8 is likely that the cells have to depolymerize the fibrils locally in order to allow septation and

9 cell division to occur. This interpretation is based on the observation that any extended

10 physical structure such as DNA or protein filaments needs to be either actively segregated or

11 locally disassembled before cell division can occur (Badrinarayanan et al., 2015; Cabeen et

12 al., 2009). Conversely, if cells lack the necessary clearing mechanisms, for example if

13 foreign filament-forming proteins are overexpressed in E. coli, cell chaining often occurs as

14 a consequence of incomplete divisions (Bharat et al., 2015). Of note, recent research has

15 revealed a possible direct link between the synthesis of OPGs and cell size control and

16 division in E. coli (Hill et al., 2013). Here one of the OPG-synthesizing enzymes, the

17 glucosyltransferase OpgH interacts with the septal ring-forming protein FtsZ and, through

18 sequestration, influences cell size and division. Through binding of UDP-glucose, OpgH

19 measures nutrient availability and relates this information directly to the cell division

20 machinery. Although this exact scenario is unlikely to be found in M. xanthus, the presence

21 of a periplasmic polymer that forms micrometer-long fibrils indicates that the cells must

22 either disassemble or segregate these structures within the periplasm for cell divisions to

23 occur. 
Agrawal et al. Running title: Bacterial osmoregulated periplasmic polymer

1 The discovery of this unique periplasmic OPG in M. xanthus identifies another major

2 cellular component in this important model organism. It will be informative to determine

3 whether other myxobacteria, $\delta$-proteobacteria or bacteria in general, produce similarly

4 complex OPGs. To a large extent this may depend on the principal function of this novel

5 type of OPG. Future studies will be needed to clarify the identity of the enzymes responsible

6 for the synthesis and assembly of the polymer, and examinations of mutants that fail to make

7 the polymer will be needed to address the specific contributions of this polymer to cellular

8 functions. Does the polymer address a specific need of the cell linked to the complex

9 behavior and physiology of $M$. xanthus, does it allow adaptation to changing osmotic

10 conditions that may be experienced by many environmental bacteria, or does it contribute to

11 both?

\section{Materials and Methods:}

\section{Bacterial Strains and Growth Conditions:}

16 The M. xanthus strains used in this study were the wild-type strain (DK1622; Kaiser, 1979)

17 and the EPS-deficient AdifE strain (YZ603; Black and Yang, 2004). Both strains were

18 routinely grown in CTT or TPM medium with or without agar (Hodgkin and Kaiser, 1977).

19 To test the influence of water limitation on the production of the periplasmic carbohydrate,

20 either no, 8 or $16 \%$ of PEG 8000 (Fluka) were added to the CTT medium, which then was

21 solidified using 1\% gelrite (Shungu et al., 1983).

\section{Isolation and Purification of the Osmoregulated Periplasmic Carbohydrate}


Agrawal et al. Running title: Bacterial osmoregulated periplasmic polymer

1 To isolate the osmoregulated periplasmic carbohydrate, wild type or $\Delta$ difE cells were grown

2 to mid-log phase in $2 \times 400 \mathrm{ml}$ CTT medium-containing flasks. This pre-culture was then

3 either expanded into $8 \times 400 \mathrm{ml}$ flasks for liquid culture or harvested in a sterile centrifuge

4 bottle, re-suspended in a small amount of medium and plated onto trays $(30 \times 40 \mathrm{~cm})$

5 containing CTT agar (or gelrite) for solid surface growth. Both liquid and agar cultures were

6 grown over night at $32{ }^{\circ} \mathrm{C}$ and harvested either by centrifugation or by scraping. The cell

7 pellets were re-suspended in $120 \mathrm{ml}$ extraction buffer $(10 \mathrm{mM}$ Tris- $\mathrm{HCl} \mathrm{pH} 8.0,10 \mathrm{mM}$

$\left.8 \mathrm{MgSO}_{4}\right)$, transferred into a household blender, and blended for $3 \mathrm{~min}$ at high speed. The cell

9 suspension was centrifuged twice to remove cells $(10 \min 27,500 \times \mathrm{g}, 10 \min 47,800 \times \mathrm{g})$

10 before $20 \%(\mathrm{w} / \mathrm{vol}$ ) ammonium sulfate was added, and the precipitated polymer was

11 collected $(15 \mathrm{~min}$ at $47,800 \times \mathrm{g})$. The pelleted polymer was re-suspended in water and

12 extracted with $0.05 \%$ (w/vol) n-dodecyl $\beta$-D-maltoside to solubilize contaminating

13 membranes. After centrifugation and re-suspension, the polymer was precipitated with

$14\left(\mathrm{NH}_{4}\right)_{2} \mathrm{SO}_{4}$, centrifuged, and either dissolved in water or kept as a pellet and used for all

15 analyses. To compare the extraction efficiency of various treatments, the cells were shaken

16 by hand for $1 \mathrm{~min}$, washed in 250 or $500 \mathrm{mM} \mathrm{NaCl}$ or treated by osmotic shock. After

17 purification, the amount of extracted polymer was weighed and the variance determined by

18 one-way ANOVA, while the p-values were calculated using the Tukey test.

19 Isolation of Canonical Periplasmic Glucans

20 Canonical osmoregulated periplasmic glucans were extracted according to standard

21 procedures (Cogez et al., 2001). Briefly, exponentially growing bacteria were harvested by

22 centrifugation $(10 \mathrm{~min} 27,500 \times \mathrm{g})$ and the pellets were extracted with $5 \%$ trichloroacetic

23 acid (TCA). After removal of the extracted cells $(10 \mathrm{~min} 27,500 \times \mathrm{g})$, the resulting 
Agrawal et al. Running title: Bacterial osmoregulated periplasmic polymer

1 supernatant was cleared of cell debris $(10 \mathrm{~min} 47,800 \times \mathrm{g})$, neutralized with ammonium

2 hydroxide, desalted using a Sephadex G-15 column, and monosaccharides were analyzed

3 after hydrolysis using $2 \mathrm{M}$ TFA for $2 \mathrm{~h}$ at $121^{\circ} \mathrm{C}$.

\section{Osmotic Shock of Cells}

5 Mid-log grown wild-type cells were harvested by centrifugation $(10 \min 27,500 \times \mathrm{g})$. The

6 cells were washed with ice-cold TM buffer (10 mM Tris- $\mathrm{HCl} \mathrm{pH} 8.0,8 \mathrm{mM} \mathrm{MgSO}_{4} ; 40 \mathrm{ml}$

7 per gram cell pellet) and the wash supernatant was kept (Tris/ $\mathrm{MgSO}_{4}$ wash). The cells were

8 centrifuged again, re-suspended in the buffer and $20 \%$ sucrose was added. After 30 min on

9 ice, the cells were centrifuged and the supernatant kept (sucrose wash). The cell pellet was

10 rapidly dispersed in ice-cold TM, centrifuged, and the supernatant containing the periplasmic

11 fraction kept (periplasm). Finally, the pelleted cells were re-suspended in $10 \mathrm{mM}$ Tris $\mathrm{pH} 7.6$

12 buffer containing cOmplete EDTA-free protease inhibitor cocktail (Roche Applied Sciences,

13 Penzberg, Germany), sonicated, and centrifuged to isolate the cytoplasmic fraction (cell

14 pellet). Both, colorimetric assays such as the anthrone test and biochemical isolations using

15 the described protocol indicated that only the periplasmic fraction contained the

16 carbohydrate polymer.

17 Alkaline Phosphatase Assay

18 The SensoLyte pNPP Alkaline Phosphatase Assay Kit (AnaSpec, Fremont, CA) was used

19 according to the manufacturer's instruction to measure the activity of the enzyme in each

20 supernatant fraction obtained from the osmotic shock procedure (Tris/ $\mathrm{MgSO}_{4}$ wash, sucrose

21 wash, periplasm, and cell pellet). Briefly, a 96 well plate was used, and $50 \mu 1$ of supernatant

22 samples or phosphatase standard solutions were pipetted into the wells. Alkaline

23 phosphatase activity was measured by adding $50 \mu 1$ of p-nitrophenyl phosphate phosphatase 
Agrawal et al. Running title: Bacterial osmoregulated periplasmic polymer

1 (pNPP) substrate solution to each of the wells. The plate was incubated for $60 \mathrm{~min}$ at room

2 temperature, shaken for $1 \mathrm{~min}$, and the absorbance measured at $405 \mathrm{~nm}$ in a plate reader

3 (BioTek Industries, Winooski, VT).

$4 \quad$ Antibody Production

5 Isolated purified periplasmic carbohydrate was injected into rabbits (Cocalico, Reamstown,

$6 \quad$ PA) to generate polyclonal antibodies according to standard protocol. Both the test bleeds

7 and the collected sera were tested for cross-reactivity using a dot blot assay and various

8 mono- and polysaccharides. The membranes were treated according to standard protocols

9 and visualized using the Pico chemiluminescent reagent (Pierce, Rockford, IL).

\section{Osmolality Measurements}

11 To determine the osmolality of solutions a Micro-Sample Osmometer Model M3 (Advanced

12 Instruments, Norwood, MA) was used. About $20 \mu \mathrm{l}$ of the samples was drawn into the

13 capillary of the sample holder and measured using freezing point depression. The instrument

14 was calibrated using standard solutions of low, medium, and high osmolality.

\section{Anthrone Test}

16 Five milliliters of freshly prepared ice-cold anthrone reagent $\left(0.2 \%\right.$ in $\left.95 \% \mathrm{H}_{2} \mathrm{SO}_{4}\right)$ were

17 added to $1 \mathrm{ml}$ of sample or variously diluted glucose standard solutions $(10 \mathrm{mg} / \mathrm{ml})$. Samples

18 were mixed, heated for $10 \mathrm{~min}$, rapidly cooled, and the absorption at $\mathrm{OD}_{620}$ determined

19 (Seifter et al., 1950).

\section{Analytical Carbohydrate Methods}

\section{Dialysis}

22 To remove salts and low-molecular-weight contaminants, the purified carbohydrate was

23 dialyzed for $48 \mathrm{~h}$ against running de-ionized water using a Slide-A-Lyzer dialysis cassette 
Agrawal et al. Running title: Bacterial osmoregulated periplasmic polymer

1 with a molecular cutoff of $20 \mathrm{kDa}$ (Pierce, Rockford, IL). Dialyzed MXP samples were

2 freeze-dried and stored at $-20{ }^{\circ} \mathrm{C}$ for further analysis.

\section{Partial Hydrolysis}

4 Five milliliters of $0.1 \mathrm{M}$ trifluoroacetic acid (TFA) were added to $20 \mathrm{mg}$ freeze-dried

5 polysaccharide, and the mixture was incubated for $2.5 \mathrm{~h}$ at $80^{\circ} \mathrm{C}$. After partial hydrolysis,

6 methanol was added the liquid was evaporated under a dry stream of $\mathrm{N}_{2}$ to remove the acid.

7 The dried samples were dissolved in de-ionized water and filtered through a $0.22 \mu \mathrm{m}$ filter to

8 give about $17 \mathrm{mg}$ MXP-A.

9 Size Exclusion High-pressure Liquid Chromatography (SEC-HPLC)

10 For carbohydrate fractionation, a Superose 12 gel filtration column (GE Healthcare Life

11 Sciences, Little Chalfont, UK) was used. A total of about $200 \mu \mathrm{g}$ partially hydrolyzed

12 polysaccharide was loaded onto the column at a concentration of ca. $1 \mathrm{mg} / \mathrm{ml}$ and eluted at a

13 flow rate of $0.5 \mathrm{ml} / \mathrm{min}$ using $50 \mathrm{mM}$ ammonium acetate buffer $\mathrm{pH}$ 5.2. Eluting

14 carbohydrates were detected with an ELS detector (evaporation temperature $70^{\circ} \mathrm{C}$, gain 9,

15 filter 5) and data were collected and processed using the Agilent ChemStation software

16 (Agilent, Santa Clara, CA). For calibration, dextran standards with average molecular

17 weights of $551,167,67,40$, and $5 \mathrm{kDa}$, as well as maltoheptaose, maltopentaose, and

18 glucose were used.

19 Smith Degradation

20 Smith degradation was carried out as described previously (MacLean and Perry, 2010). The

21 MXP-A $(\sim 4.5 \mathrm{mg})$ in water containing sodium metaperiodate $\left(\mathrm{NaIO}_{4}, 9 \mathrm{mg} / 450 \mu \mathrm{L}\right)$ was

22 kept in the dark at $20{ }^{\circ} \mathrm{C}$ for $20 \mathrm{~h}$. Following the addition of glycol $(0.1 \mathrm{~mL})$, the reaction

23 mixture was dialyzed against 3 changes of $4 \mathrm{~L}$ deionized water. The retentate was treated 
Agrawal et al. Running title: Bacterial osmoregulated periplasmic polymer

1 with $\mathrm{NaBH}_{4}(10 \mathrm{mg} / 2 \mathrm{~mL}$ water, $4 \mathrm{~h})$, followed by neutralization (AcOH) and further

2 dialysis. The concentrated retentate was dissolved in $1 \mathrm{M}$ hydrochloric acid (2 mL) and was

3 kept at room temperature for $16 \mathrm{~h}$, diluted with water, and the lyophilized product was

4 fractionated by SEC column chromatography to yield several fractions.

\section{Glycosyl Composition Analysis}

6 Glycosyl composition analysis was performed by combined gas chromatography/mass

7 spectrometry (GC-MS) of the per- $O$-trimethylsilyl (TMS) derivatives of the monosaccharide

8 methyl glycosides generated by acidic methanolysis (Santander at al., 2013; Edgar et al.,

9 2016). Briefly, sample aliquots were added into separate tubes containing $20 \mu \mathrm{g}$ inositol as

10 internal standard. After drying, methyl glycosides were prepared by mild acid treatment by

11 methanolysis in $1 \mathrm{M} \mathrm{HCl}$ in methanol at $80{ }^{\circ} \mathrm{C}$ for $16 \mathrm{~h}$, followed by re- $N$-acetylation with

12 pyridine and acetic anhydride in methanol (for detection of amino sugars). Samples were

13 then per- $O$-trimethylsilylated at $80{ }^{\circ} \mathrm{C}$ for $0.5 \mathrm{~h}$ using Tri-Sil (Pierce, Rockford, IL),

14 separated on an Agilent DB-1 fused silica capillary column $(30 \mathrm{~m} \times 0.25 \mathrm{~mm})$, and analyzed

15 by GC-MS using an Agilent 7890A GC interfaced to an Agilent 5975C mass selective

16 detector (MSD).

17 Glycosyl Linkage Analysis

18 For glycosyl linkage analysis, samples were permethylated, depolymerized, reduced, and

19 acetylated, and the resulting partially methylated alditol acetates (PMAAs) analyzed by GC-

20 MS as described previously (Heiss et al., 2009), but with slight modifications. Briefly, dry

21 carbohydrate samples were suspended in $200 \mu$ of dimethyl sulfoxide (DMSO) and

22 continuously stirred for 1-2 weeks. The samples were then permethylated through treatment

23 with sodium hydroxide and methyl iodide in dry DMSO. To ensure complete methylation of 
Agrawal et al. Running title: Bacterial osmoregulated periplasmic polymer

1 the polymer, the procedure was carried out in two steps. Initially, the polymer was subjected

2 to $\mathrm{NaOH}$ for $15 \mathrm{~min}$, before methyl iodide was added and left for $45 \mathrm{~min}$. In the second step,

3 additional base was added for $10 \mathrm{~min}$, followed by more methyl iodide for another $40 \mathrm{~min}$.

4 The permethylated polymer was hydrolyzed using $2 \mathrm{M}$ TFA for $2 \mathrm{~h}$ at $121^{\circ} \mathrm{C}$, reduced with

$5 \mathrm{NaBD}_{4}$ and acetylated with a mixture of acetic anhydride and TFA. The resulting PMAAs

6 were separated on a $30 \mathrm{~m} \times 0.25 \mathrm{~mm}$ ID Supelco 2380 bonded phase fused silica capillary

7 column (for neutral sugars) and on a $30 \mathrm{~m} \times 0.25 \mathrm{~mm}$ ID Phenomenex ZB-1MS column (for

8 amino sugars) and analyzed on an Agilent 7890A GC interfaced to a 5975C MSD using

9 electron impact ionization mode.

\section{NMR Spectroscopy}

11 Polymer samples were deuterium exchanged by dissolving in $\mathrm{D}_{2} \mathrm{O}$ and lyophilizing. After

12 deuterium-exchange, the sample was dissolved in $0.5 \mathrm{ml} \mathrm{D}_{2} \mathrm{O}$ and placed into a $5 \mathrm{~mm} \mathrm{NMR}$

13 tube. 1-D proton and 2-D gCOSY, TOCSY, gHSQC, gHMBC, NOESY spectra were

14 obtained on a Varian Inova 600 and $800 \mathrm{MHz}$ spectrometer (Agilent Technologies, Palo

15 Alto, CA) at $45^{\circ} \mathrm{C}$ using standard Varian pulse sequences. Chemical shifts were measured

16 relative to internal acetone $\left(\delta_{\mathrm{H}}=2.218, \delta_{\mathrm{C}}=33.0 \mathrm{ppm}\right)$.

\section{Glycerol Spore Formation}

18 To analyze rod-to-spore morphogenesis, cells were grown on trays with gelrite-solidified

19 CTT medium with or without PEG, harvested, and re-suspended in $25 \mathrm{ml}$ of CTT medium.

20 Spore formation was induced by adding $0.5 \mathrm{M}$ glycerol to the medium either immediately

21 following the re-suspension or after an initial incubation of the cells for $1.5 \mathrm{~h}$ at $32{ }^{\circ} \mathrm{C}$.

22 Samples were collected after shaking at $250 \mathrm{rpm}$ for $0,15,30,60,90,120,180$, and $240 \mathrm{~min}$

23 at $32{ }^{\circ} \mathrm{C}$, fixed and analyzed using the light microscope (Dworkin and Gibson, 1964). The 
Agrawal et al. Running title: Bacterial osmoregulated periplasmic polymer

1 assay was performed three times in triplicate. To determine the rate of conversion one

2 hundred randomly selected cells were counted and the number of spherical spores vs.

3 vegetative cells determined.

4 Electron and Light Microscopy

5 Negative staining was used to examine the structure of the isolated periplasmic polymer.

6 Glow discharged-treated 400 mesh carbon-coated copper grids were placed on top of a drop

7 containing water-dissolved polymer for 1-2 min and stained with either un-buffered $2 \%$

8 uranyl acetate or $\mathrm{pH}$ 7.5-buffered $2 \%$ phosphotungstic acid. For cryo-immuno electron

9 microscopy, cells were processed using standard procedures (Tokuyasu, 1973). Sections

10 were cut with a Leica UCT cryo-microtome (Leica Microsystems, Buffalo Grove, IL) and

11 picked up on 200 mesh formvar-coated glow discharged nickel grids. For labeling, the grids

12 were transferred onto drops of PBS containing the primary antibody at concentrations of

13 1:500, 1:1000, or 1:2000 and incubated overnight at $4{ }^{\circ} \mathrm{C}$. Detection of the primary antibody

14 was done with $12 \mathrm{~nm}$ gold-labeled goat anti-rabbit secondary antibody (Jackson

15 ImmunoResearch, West Grove, PA) diluted 1:20 in PBS for one hour at room temperature.

16 Finally, the thin sections were contrasted using $2 \%$ methylcellulose containing $0.3 \%$ uranyl

17 acetate for $10 \mathrm{~min}$ at $4{ }^{\circ} \mathrm{C}$. Samples were viewed with a Philips CM120 (FEI, Hillsboro, OR)

18 or a Zeiss Libra (Zeiss, Thornhill, NJ) electron microscope operating at $80 \mathrm{kV}$ and pictures

19 were recorded using a $4 \times 4$ ORCA CCD camera (Hamamatsu, Middlesex, NJ). A Nikon

20 E800 light microscope equipped with a 100× oil immersion phase contrast objective was

21 used to take pictures of the glycerol spore formation (Nikon Instruments, Melville, NY). All

22 recorded images were imported into Adobe Photoshop and digitally processed for 
Agrawal et al. Running title: Bacterial osmoregulated periplasmic polymer

1 publication. If the contrast was adjusted, it was applied to the entire image. No other form of

2 digital alteration was performed.

\section{Bioinformatics}

$4 \quad \mathrm{OpgG}$ and $\mathrm{OpgH}$ homologues in various bacteria were identified using standard BLAST

5 searches (Altschul et al., 1990). The identified sequences were then used to generate a

6 multiple sequence alignment using Clustal Omega (Madeira et al., 2019), which was

7 visualized with Jalview2 (Waterhouse et al., 2009).

8 
Agrawal et al. $\quad$ Running title: Bacterial osmoregulated periplasmic polymer

\section{ACKNOWLEDGMENTS}

2 We would like to thank past and present members of the Hoiczyk laboratory for helpful

3 discussions and comments on the work and the manuscript, Carol Cooke for help with the

4 immuno-EM work, Mike Delannoy for assistance with osmolality measurements, Jane Voss

5 for help with the photography, and Sara Porfirio for proof reading. This work was started at

6 Johns Hopkins Bloomberg School of Public Health and then continued and finished at the

7 University of Sheffield. The initial research was funded by a Sommer Scholar Fellowship (to

8 S.A.), while completion was supported by funds of the Imagine initiative of the University of

9 Sheffield (D.M.Z., K.S, J.M.T.S. and E.H.) and the BBSRC (E.H.). The work at the

10 Complex Carbohydrate Center was supported by the Chemical Sciences, Geosciences and

11 Biosciences Division, Office of Basic Energy Sciences, U.S. Department of Energy grant

12 (DE-SC0015662 to P.A.). 
Agrawal et al. Running title: Bacterial osmoregulated periplasmic polymer

\section{References}

3 Altschul SF, Gish W, Miller W, Myers EW, Lipman DJ (1990) Basic local alignment search 4 tool. J Mol Biol 215(3):403-410.

6 Badrinarayanan A, Le TB, Laub MT (2015) Bacterial chromosome organization and 7 segregation. Annu Rev Cell Dev Biol 31:171-199.

9 Berleman JE, Scott J, Chumley T, Kirby JR (2008) Predataxis behavior in Myxococcus 10 xanthus. Proc Natl Acad Sci USA 105(44):17127-17132.

12 Berleman JE, Kirby JR (2009) Deciphering the hunting strategy of a bacterial wolfpack.

13 FEMS Microbiol Rev 33(5):942-957.

15 Berleman J, Auer M (2013) The role of bacterial outer membrane vesicles for intra- and 16 interspecies delivery. Environ Microbiol 15(2):347-354.

19 filaments show architecture of plasmid-segregating spindles. Nature 523(7558):106-110.

21 Black WP, Yang Z (2004) Myxococcus xanthus chemotaxis homologs DifD and DifG 22 negatively regulate fibril polysaccharide production. J Bacteriol 186(4):1001-1008. 
Agrawal et al. Running title: Bacterial osmoregulated periplasmic polymer

1 Bohin J-P (2000) Osmoregulated periplasmic glucans in proteobacteria. FEMS Microbiol

2 Lett 186(1):11-19.

3

4 Bontemps-Gallo S, Lacroix J-M (2015) New insights into the biological role of the

5 osmoregulated periplasmic glucans in pathogenic and symbiotic bacteria. Environ Microbiol

$6 \quad \operatorname{Rep} 7(5): 690-697$.

7

8 Bontemps-Gallo S, Bohin J-P, Lacroix J-M (2017) Osmoregulated periplasmic glucans.

9 EcoSal Plus 7(2):doi:10.1128/ecosalplus.EPS-0001-2017.

10

11 Bui NK, Gray J, Schwarz H, Schumann P, Blanot D, Vollmer W (2009) The peptidoglycan

12 sacculus of Myxососсиs xanthus has unusual structural features and is degraded during

13 glycerol-induced myxospore development. J Bacteriol 191(2):494-505.

15 Burchard RP (1981) Gliding motility in prokaryotes: ultrastructure, physiology, and 16 genetics. Annu Rev Microbiol 35:497-529.

18 Burchard RP (1982) Evidence for contractile flexing of the gliding bacterium Flexibacter

19 FS-1. Nature 298(5875):663-665.

21 Cabeen MT, Charbon G, Vollmer W, Born P, Ausmess N, Weibel DB, Jacobs-Wagner C

22 (2009) Bacterial cell curvature through mechanical control of cell growth. EMBO J 23 28(9):1208-1219. 
Agrawal et al. Running title: Bacterial osmoregulated periplasmic polymer

2 Chang W-S, van de Mortel M, Nielsen L, de Guzman GN, Li X, Halverson LJ (2007)

3 Alginate production by Pseudomonas putida creates hydrated microenvironments and

4 contributes to biofilm architecture and stress tolerance under water-limiting conditions. $J$

5 Bacteriol 189(22):8290-8299.

6

7 Chang YW, Rettberg LA, Treuner-Lange A, Iwasa J, Søgaard-Andersen L, Jensen GJ (2016)

8 Architecture of the type IVa pilus machine. Science 351(6282):aad2001.

10 Cogez V, Talaga P, Lemoine J, Bohin J-P (2001) Osmoregulated periplasmic glucans of 11 Erwinia chrysanthemi. J Bacteriol 183(10):3127-3133.

13 Ducret A, Fleuchot B, Bergam P, Mignot T (2013) Direct life imaging of cell-cell protein 14 transfer by transient outer membrane fusion. Elife 2:e00868.

16 Duus J, Gotfredsen CH, Bock K (2000) Carbohydrate structural determination by NMR 17 spectroscopy: modern methods and limitations. Chem Rev 100(12):4589-4614.

19 Dworkin M, Gibson SM (1964) A system for studying microbial morphogenesis: rapid 20 formation of microcysts in Myxococcus xanthus. Science 146(3641):243-244.

22 Dziewanowska K, Settles M, Hunter S, Linquist I, Schilkey F, Hartzell PL (2014) Phase 23 variation in Myxococcus xanthus yields cells specialized for iron sequestration. PLoS ONE 
Agrawal et al. Running title: Bacterial osmoregulated periplasmic polymer

$19(4): \mathrm{e} 95189$.

2

3 Edgar RJ, Chen J, Kant S, Rechkina E, Rush JS, Forsberg LS, Jaehrig B, Azadi P,

4 Tchesnokova V, Sokurenko EV, Zhu H, Korotkov KV, Pancholi V, Korotkova N (2016)

5 SpyB, a Small Heme-Binding Protein, Affects the Composition of the Cell Wall in

6 Streptococcus pyogenes. Front Cell Infect Microbiol 6:126.

8 Ehrmann M (2006) The periplasm. (ASM Press, Washington DC).

10 Emerson D, Rentz JA, Lilburn TG, Davis RE, Aldrich H, Chan C, Moyer CL (2007) A novel

11 lineage of Proteobacteria involved in formation of marine Fe-oxidizing microbial mat 12 communities. PLoS ONE 2(8):e667.

14 Faure LM, Fiche JB, Espinosa L, Ducret A, Anantharaman V, Luciano J, Lhospice S, Islam 15 ST, Tréguier J, Sotes M, Kuru E, Van Nieuwenhze MS, Brun YV, Théodoly O, Aravind L, 16 Nollman M, Mignot T (2016) The mechanism of force transmission at bacterial focal 17 adhesion complexes. Nature 539(7630):530-535.

19 Furusawa G, Dziewanowska K, Stone H, Settles M, Hartzell P (2011) Global analysis of 20 phase variation in Myxococcus xanthus. Mol Microbiol 81(3):784-804.

22 Geiger O, Weissborn AC, Kennedy EP (1991) Biosynthesis and excretion of cyclic glucans 23 by Rhizobium meliloti 1021. J Bacteriol 173(9):3021-3024. 
Agrawal et al. Running title: Bacterial osmoregulated periplasmic polymer

2 Goldman BS, Nierman WC, Kaiser D, Slater SC, Durkin AS, Eisen JA, Ronning CM,

3 Barbazuk WB, Blanchard M, Field C, Halling C, Hinkle G, Iartchuk O, Kim HS, Mackenzie

4 C, Madupu R, Miller N, Shvartsbeyn A, Sullivan SA, Vaudin M, Wiegand R, Kaplan HB

5 (2006) Evolution of sensory complexity recorded in a myxobacterial genome. Proc Natl

6 Acad Sci USA 103(41):15200-15205.

8 Heiss C, Klutts JS, Wang Z, Doering TL, Azadi P (2009) The structure of Cryptococcus 9 neoformans galactoxylomannan contains beta-D-glucuronic acid. Carbohydr Res $10 \quad 344(7): 915-920$.

12 Hiagler CH (1985) The functions and biogenesis of native cellulose. Cellulose chemistry and 13 its applications, eds Nevell TP, Zeronian SH (Ellis Horwood Limited), pp 30-83.

15 Higgins D, Dworkin J (2012) Recent progress in Bacillus subtilis sporulation. FEMS 16 Microbiol Rev 36(1):131-148.

18 Higgs PI, Hartzell PL, Holkenbrink C, Hoiczyk E (2014) Myxococcus xanthus vegetative 19 and developmental cell heterogeneity. Molecular and developmental biology of 20 myxobacteria, eds Yang Z, Higgs PI (Horizon Scientific Press, Norfolk), pp 51-78.

22 Hill NS, Buske PJ, Shi Y, Levin PA (2013) A moonlighting enzyme links Escherichia coli 23 cell size with central metabolism. PLoS Genet 9:e1003663. 
Agrawal et al. Running title: Bacterial osmoregulated periplasmic polymer

2 Hodgkin J, Kaiser D (1977) Cell-to-cell stimulation of movement in nonmotile mutants of

3 Myxococcus. Proc Natl Acad Sci USA 74(7):2938-2942.

4

5 Holkenbrink C, Hoiczyk E, Kahnt J, Higgs PI (2014) Synthesis and assembly of a novel

6 glycan layer in Myxococcus xanthus spores. J Biol Chem 289(46):32364-32378.

8 Islam ST, Mignot T (2015) The mysterious nature of bacterial surface (gliding) motility: a

9 focal adhesion-based mechanism in Myxococcus xanthus. Semin Cell Dev Biol 46:143-154.

11 Jakob HF, Fengel D, Tschegg SE, Fratzl P (1995) The elementary cellulose fibril in Picea 12 abies: comparison of transmission electron microscopy, small-angle X-ray scattering, and 13 wide-angle X-ray scattering results. Macromolecules 28(26):8782-8787.

15 Jones, MV, Dawson H, Wells VE, Perkins HR (1981) Growth and cellular differentiation of 16 Myxococcus xanthus in the presence of $\beta$-lactam antibiotics. J Gen Microbiol 124(2):28117290.

19 Kaiser D (1979) Social gliding is correlated with the presence of pili in Myxococcus xanthus. 20 Proc Natl Acad Sci USA 76(11):5952-5956.

22 Kennedy EP (1982) Osmotic regulation and the biosynthesis of membrane-derived 23 oligosaccharides in Escherichia coli. Proc Natl Acad Sci USA 79(4):1092-1095. 
Agrawal et al. Running title: Bacterial osmoregulated periplasmic polymer

2 Kulp A, Kuehn MJ (2010) Biological functions and biogenesis of secreted bacterial outer

3 membrane vesicles. Annu Rev Microbiol 64:163-184.

4

5 Lee S, Cho E, Jung S (2009) Periplasmic glucans isolated from proteobacteria. BMB Reports $6 \quad 42(12): 769-775$.

8 Lu A, Cho K, Black WP, Duan XY, Lux R, Yang Z, Kaplan HB, Zusman DR, Shi W (2005)

9 Exopolysaccharide synthesis genes required for social motility in Myxococcus xanthus. Mol 10 Microbiol 55(1):206-220.

12 MacLean LL, Perry MB (2010) Characterization of the antigenic O-polysaccharide produced 13 by Escherichia coli serotype O:70. Carbohydr Res 345(5):644-648.

15 Madeira F, Park YM, Lee J, Buso N, Gur T, Madhusoodanan N, Batsutkar P, Tivey ARN, 16 Potter SC, Finn RD, Lopez R (2019) The EMBL-EBI search and sequence analysis tools 17 APIs in 2019. Nucleic Acids Res 47(W1):W636-W641.

19 McHugh CA, Fontana J, Nemecek D, Cheng N, Aksyuk AA, Heymann JB, Winkler DC, 20 Lam AS, Wall JS, Steven AC, Hoiczyk E (2014) A virus capsid-like nanocompartment that 21 stores iron and protects bacteria from oxidative stress. EMBO J 33(17):1896-1911.

23 McIntire FC, Peterson WH, Riker AJ (1942) A polysaccharide produced by the crown-gall 
Agrawal et al. Running title: Bacterial osmoregulated periplasmic polymer

1 organism. J Biol Chem 143(2):491-496.

2

3 McKenney PT, Driks A, Eichenberger P (2013) The Bacillus subtilis endospore: assembly

4 and function of the multilayered coat. Nat Rev Microbiol 11(1):33-44.

5

6 Merkle RK, Poppe I (1994) Carbohydrate composition analysis of glycoconjugates by gas-

7 liquid chromatography/mass spectrometry. Methods Enzymol 230:1-15.

9 Mignot T, Shaevitz J, Hartzell P, Zusman DR (2007) Evidence that focal adhesion 10 complexes power bacterial gliding motility. Science 315(5813):853-856.

12 Miller KJ, Wood JM (1996) Osmoadaptation by rhizosphere bacteria. Annu Rev Microbiol $13 \quad 50: 101-136$.

15 Miller KJ, Kennedy EP, Reinhold VN (1986) Osmotic adaptation by gram-negative bacteria:

16 possible role for periplasmic oligosaccharides. Science 231(4733):48-51.

17

18 Nan B (2017) Bacterial gliding motility: rolling out a consensus model. Curr Biol 19 27(4):R139-R161.

20

21 Nan B, Mauriello EM, Sun IH, Wang A, Zusman DR (2010) A multi-protein complex from 22 Myxococcus xanthus required for bacterial gliding motility. Mol Microbiol 76(6):1539-1554. 
Agrawal et al. Running title: Bacterial osmoregulated periplasmic polymer

1 Nan B, McBride MJ, Chen J, Zusman DR, Oster G (2014) Bacteria that glide with helical

2 tracks. Curr Biol 24(4):R169-R173.

3

4 Nossal, NG, Heppel LA (1966) The release of enzymes by osmotic shock from Escherichia

$5 \quad$ coli in exponential phase. J Biol Chem 241(13):3055-3062.

6

7 Palsdottir H, Remis JP, Schaudinn C, O’Toole E, Lux R, Shi W, MacDonald KL, Costerton

8 JW, Auer M (2009) Three-dimensional macromolecular organization of cryofixed

9 Myxococcus xanthus biofilms as revealed by electron microscopic tomography. J Bacteriol $10 \quad$ 191(7):2077-2082.

11

12 Pathak DT, Wei X, Wall D (2012) Myxobacterial tools for social interactions. Res Microbiol 13 163(9-10):579-591.

15 Perlin AS (2006) Glycol-cleavage oxidation. Adv Carbohydr Chem Biochem 60:183-250.

16

17 Pettolino FA, Walsh C, Fincher GB, Bacic A (2012) Determining the polysaccharide

18 composition of plant cell walls. Nat Protoc 7(9):1590-1607.

19

20 Rodriguez-Soto JP, Kaiser D (1997) Identification and localization of the Tgl protein, which

21 is required for Myxococcus xanthus social motility. J Bacteriol 179(13):4372-4381.

22

23 Santander J, Martin T, Loh A, Pohlenz C, Gatlin DM $3^{\text {rd }}$, Curtiss R $3^{\text {rd }}$ (2013) Mechanisms 
Agrawal et al. $\quad$ Running title: Bacterial osmoregulated periplasmic polymer

1 of intrinsic resistance to antimicrobial peptides of Edwardsiella ictaluri and its influence on

2 fish gut inflammation and virulence. Microbiology 159(7):1471-1486.

3

4 Schulman H, Kennedy EP (1979) Localization of membrane-derived oligosaccharides in the 5 outer envelope of Escherichia coli and their occurrence in other Gram-negative bacteria. $J$ 6 Bacteriol 137(1):686-688.

8 Seifter S, Dayton S, Novic B, Muntwyler E (1950) The estimation of glycogen with the 9 anthrone reagent. Arch Biochem 25(1):191-200.

11 Shungu D, Valiant M, Tutlane V, Weinberg E, Weissberger B, Koupal L, Gadebusch H, 12 Stapley E (1983) Gelrite as an agar substitute in bacteriological media. Appl Environ 13 Microbiol 46(4):840-845.

15 Stevens A, Søgaard-Andersen L (2005) Making waves: pattern formation by a cell-surface16 associated signal. Trends Microbiol 13(6):249-252.

18 Tokuyasu KT (1973) A technique for ultracryotomy of cell suspensions and tissues. J Cell 19 Biol 57(2):551-565.

21 Van Golde LMG, Schulman H, Kennedy EP (1973) Metabolism of membrane phospholipids and its relation to a novel class of oligosaccharides in Escherichia coli. Proc Natl Acad Sci USA 70(5):1368-1372. 
Agrawal et al. $\quad$ Running title: Bacterial osmoregulated periplasmic polymer

2 Vasallo C, Pathak DT, Cao P, Zuckerman DM, Hoiczyk E, Wall D (2015) Cell rejuvenation

3 and social behaviors promoted by LPS exchange in myxobacteria. Proc Natl Acad Sci USA

$4 \quad 112(22): E 2939-E 2946$.

5

6 Vasallo CN, Cao P, Conklin A, Finkelstein H, Hayes CS, Wall D (2017) Infectious

7 polymorphic toxins delivered by outer membrane exchange discriminate kin in 8 myxobacteria. Elife 6:e29397.

10 Velicer GJ, Vos M (2009) Sociobiology of the myxobacteria. Annu Rev Microbiol 63:59911623.

13 Waterhouse AM, Procter JB, Martin DMA, Clamp M, Barton GJ (2009) Jalview version 2 14 a multiple alignment editor and analysis workbench. Bioinformatics 25(9):1189-1191.

16 Wei X, Vassallo CN, Pathak DT, Wall D (2014) Myxobacteria produce outer membrane 17 enclosed tubes in unstructured environments. J Bacteriol 196(10):1807-1814.

19 White D, Dworkin M, Tipper DJ (1968) Peptidoglycan of Myxococcus xanthus: structure 20 and relation to morphogenesis. J Bacteriol 95(6):2186-2197.

22 Wolgemuth CW (2005) Force and flexibility of flailing myxobacteria. Biophys J 89(2):94523950. 
Agrawal et al. Running title: Bacterial osmoregulated periplasmic polymer

2 Wood JM (2011) Bacterial osmoregulation: a paradigm for the study of cellular homeostasis.

3 Annu Rev Microbiol 65:215-238.

4

5 York WS, Darvill AG, McNeil M, Stevenson TT, Albersheim P (1985) Isolation and

6 characterization of plant cell walls and cell-wall components. Methods Enzymol 118:3-40.

7

8 Zusman DR, Scott AE, Yang Z, Kirby JR (2007) Chemosensory pathways, motility and

9 development in Myxococcus xanthus. Nat Rev Microbiol 5(11):862-872.

10 
Agrawal et al. Running title: Bacterial osmoregulated periplasmic polymer

\section{Figure legends:}

3 Fig. 1. Myxococcus xanthus cells produce a high-MW polymer that can be extracted by

4 subjecting the cells to high shear forces. (A) The released purified polymer increases the 5 viscosity of water visible through the trapping of bubbles and $(B)$ can be pelleted using

6 ammonium sulfate. $(C)$ In negatively stained preparations, the isolated polymer is composed

7 of thin fibrils ca. $4 \mathrm{~nm}$ wide that often bundle into larger fibers forming a fibrillar meshwork.

8 Bar, $0.5 \mu \mathrm{m} .(D)$ After partial hydrolysis the molecule fragments and the fraction containing

9 the ca. $400 \mathrm{kDa}$ large fragment (high-molecular-weight, HMW) was isolated and used for 10 chemical analyses.

13 Fig. 2. A high-MW polymer localizes to the periplasm of Myxococcus xanthus. (A) Cryo-

14 immuno electron microscopy reveals that an anti-polymer antibody labels the cell envelope 15 of $\triangle$ difE cells in thin sections. $(B)$ Detection of the release of the polymer under various 16 treatment regiments. Only treatments that rupture the outer membrane, such as sucrose shock 17 and high-speed blending, release the polymer, whereas procedures aimed at extracting 18 extracellular polysaccharides, such as salt washes, are ineffective. The variance was 19 determined by one-way ANOVA and p-values were calculated with the Tukey test. (C) 20 Alkaline phosphatase, a known periplasmic enzyme is released under the same conditions as 21 the polymer. The black bars show the experimental data, while the grey bars are from 22 Rodriguez-Soto and Kaiser, 1997 (no Tris/ $\mathrm{MgSO}_{4}$ wash was performed by these authors).

23 (D) Release of EncA during various cell treatments. The cytoplasmic protein EncA was used 
Agrawal et al. Running title: Bacterial osmoregulated periplasmic polymer

1 to monitor the release of cytoplasmic content during various treatments of cells used to

2 extract the periplasmic polymer. Conditions that breach the outer membrane and release the

3 polymer release only small amounts of EncA, indicating that the cytoplasmic membrane is

4 not substantially breached under these conditions. Lane 1, Tris/ $\mathrm{MgSO}_{4}$ wash; lane 2, sucrose

5 wash; lane 3, periplasm; lane 4, cell pellet.

8 Figure 3. Elucidation of the chemical structure of the Myxococcus xanthus periplasmic high-

9 MW carbohydrate (MXP). (A) Proposed chemical structure of the pentasaccharide repeat 10 unit of the Smith-degraded MXP (MXP-AS). MXP-AS represents the core structure of the $11 \mathrm{MXP} ;(B)$ linkages to the core structure MXP-AS that are cleaved during Smith degradation, 12 based upon the linkage analysis results; $(C)$ proposed structure of the decasaccharide repeat 13 unit of the MXP and its product after mild acid hydrolysis with 0.1 M TFA (MXP-A).

16 Fig. 4. The Myxococcus xanthus high-MW carbohydrate is only produced by cells grown at 17 low osmolarity. (A) Comparison of the amount of isolated crude polymer of cells grown 18 under different osmotic conditions. Note that upon further purification no polymer can be 19 recovered from the cells grown with $16 \%$ PEG. (B) Size exclusion chromatography of 20 isolated polymer after extraction from cells grown under different osmotic conditions. The $21400 \mathrm{kDa}$ polymer peak decreases under intermediate (8\% PEG) and disappears at high osmolarity (16\% PEG). The peak that is present in all three isolations towards the end of the 23 column runs does not contain carbohydrate. 
Agrawal et al. Running title: Bacterial osmoregulated periplasmic polymer

3 Fig. 5. The presence of the high-MW polymer is correlated with the ability for cells to

4 convert from rods to spores upon glycerol-induced sporulation. The column on the left

5 shows wild type cells grown under low osmolarity in CTT medium. Under these conditions

6 the cells contain large amounts of the polymer and nearly $100 \%$ convert to spores within ca.

$72 \mathrm{~h}$ following induction. The cells on right were grown at high osmolarity in the presence of

$8 \quad 16 \%$ PEG. These cells completely lack the periplasmic polymer and convert to glycerol

9 spores substantially slower and to a greatly-reduced extent. Moreover, many of the

10 converting cells do not complete the conversion but form shortened egg- or loaf-shaped cells

11 instead. The small numbers in the pictures denote the percentage of cells converted to spores

12 at each time point. 

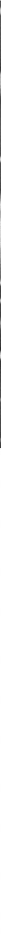

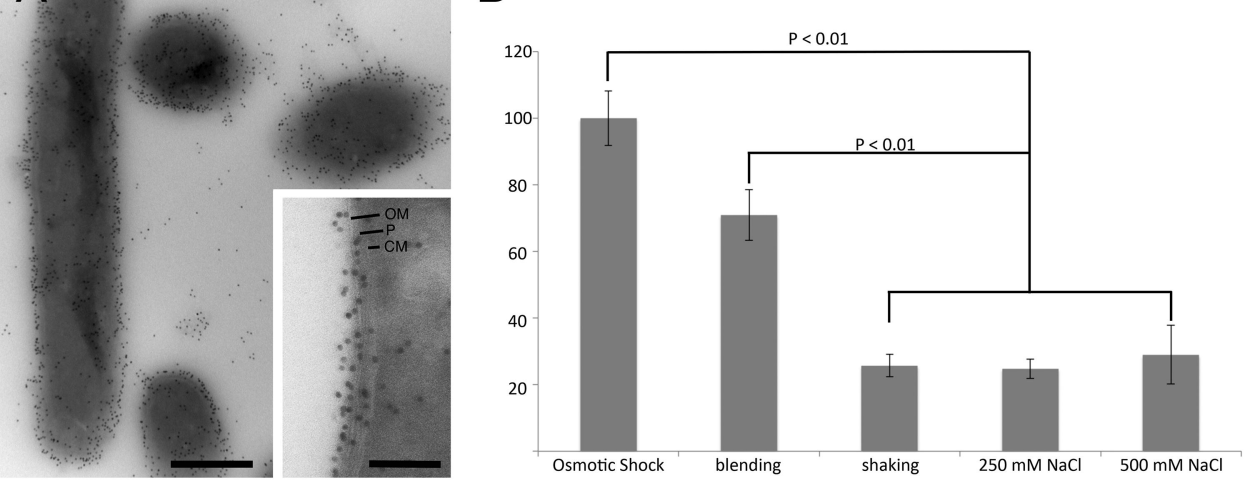

C
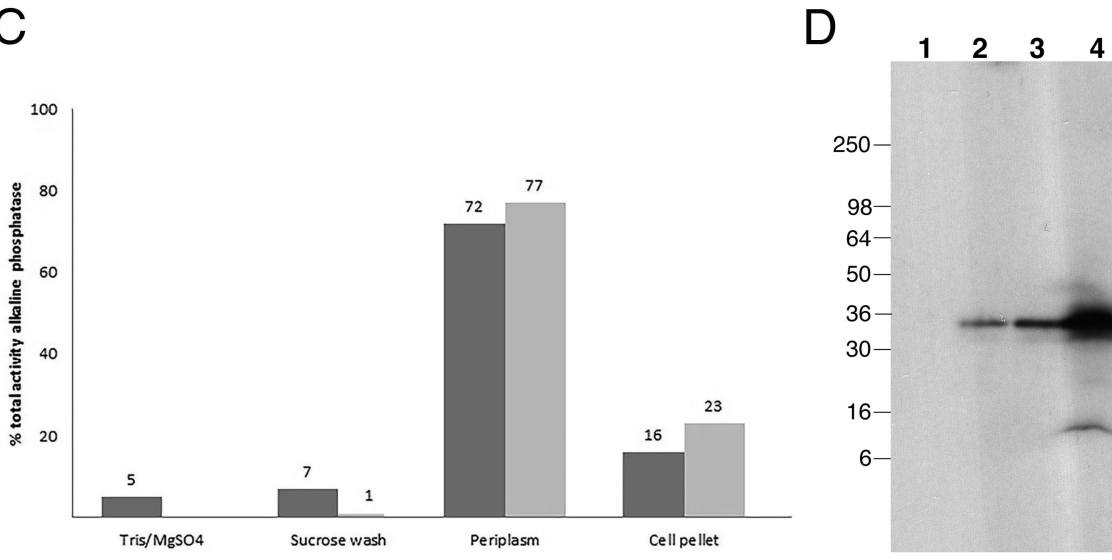

98-

$64-$

$50-$

$36-$

30-

16-

$6-$ 
A

MXP-AS
B

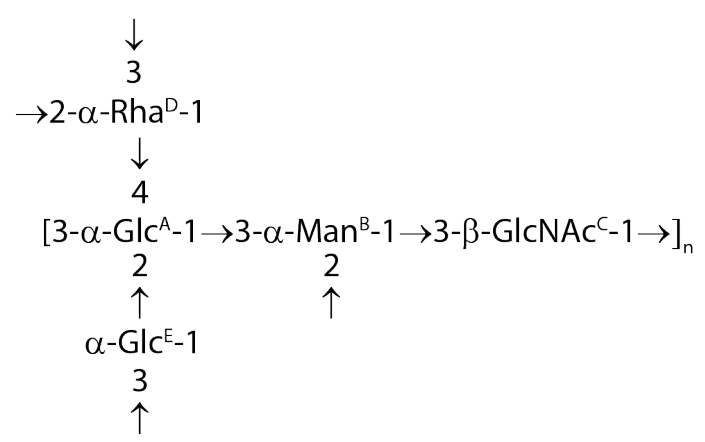

$\alpha-G \mid c N A c^{F}-1$
$\downarrow$
3

Rha- $1 \rightarrow 4-$ Rha- $1 \rightarrow 2-\alpha-$ Rha $^{\mathrm{D}}-1$

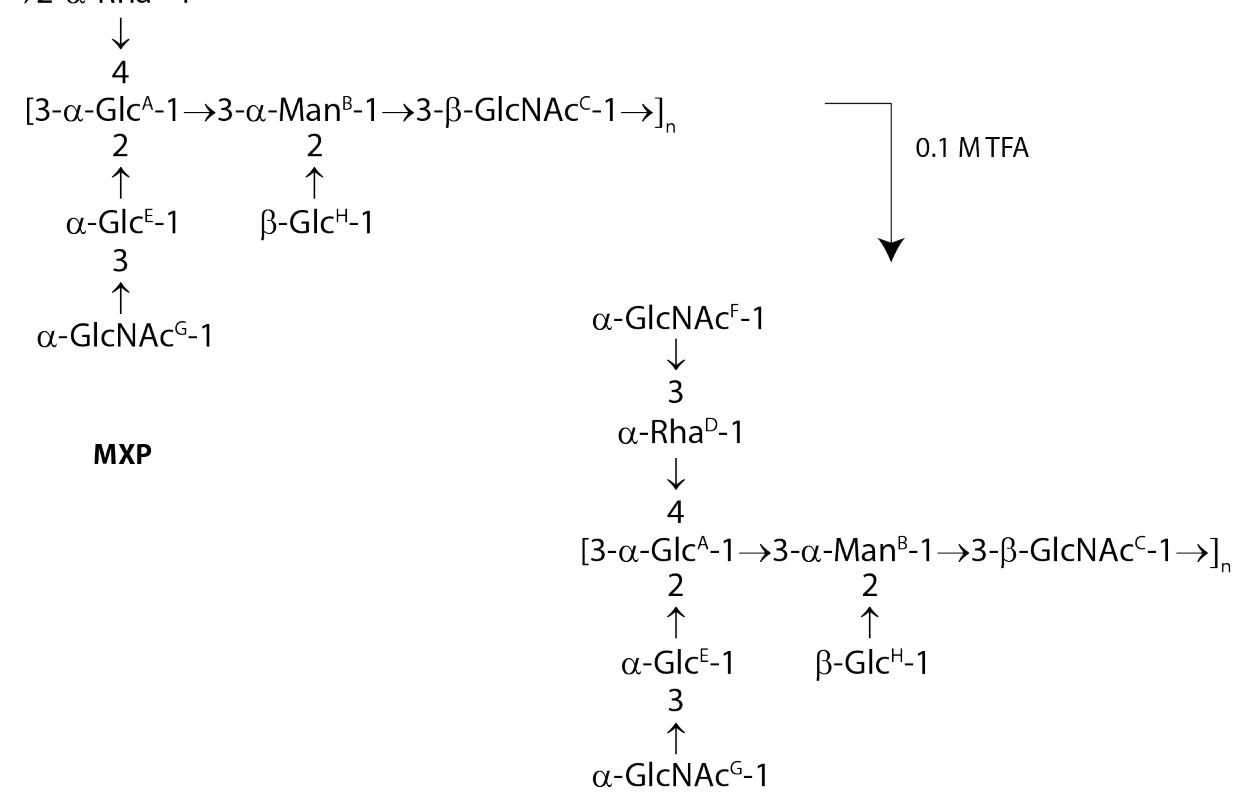

MXP-A 
A

\section{$100 \%$ \\ $31.6 \%$ \\ $10.3 \%$}

\section{B}

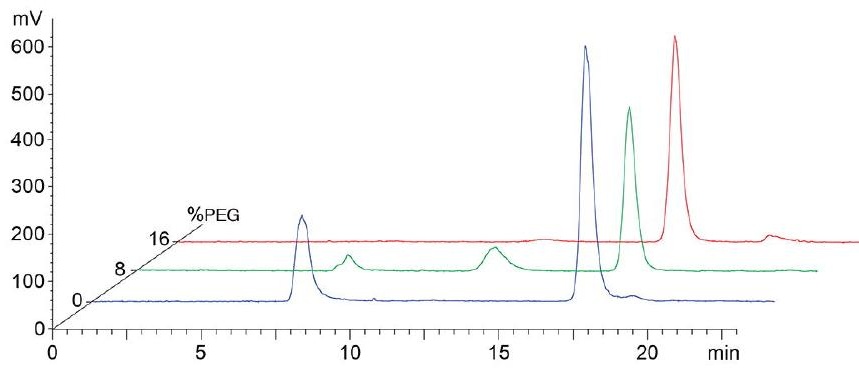



was not certified by peer review) is the author/funder. All rights reserved. No reuse allowed CTT

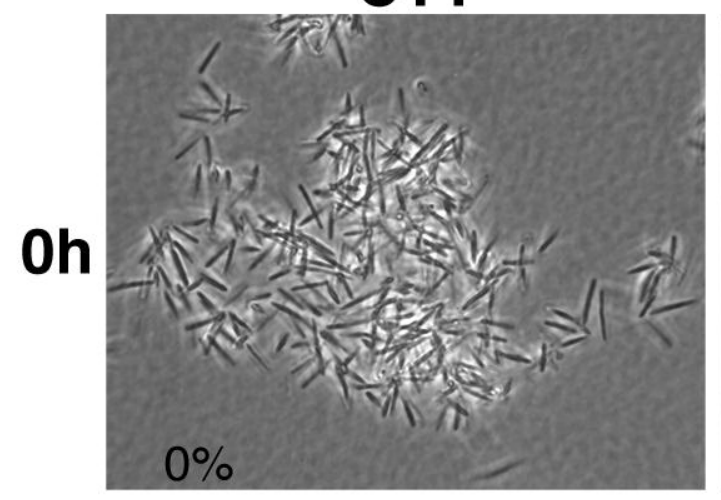

CTT+16\%PEG
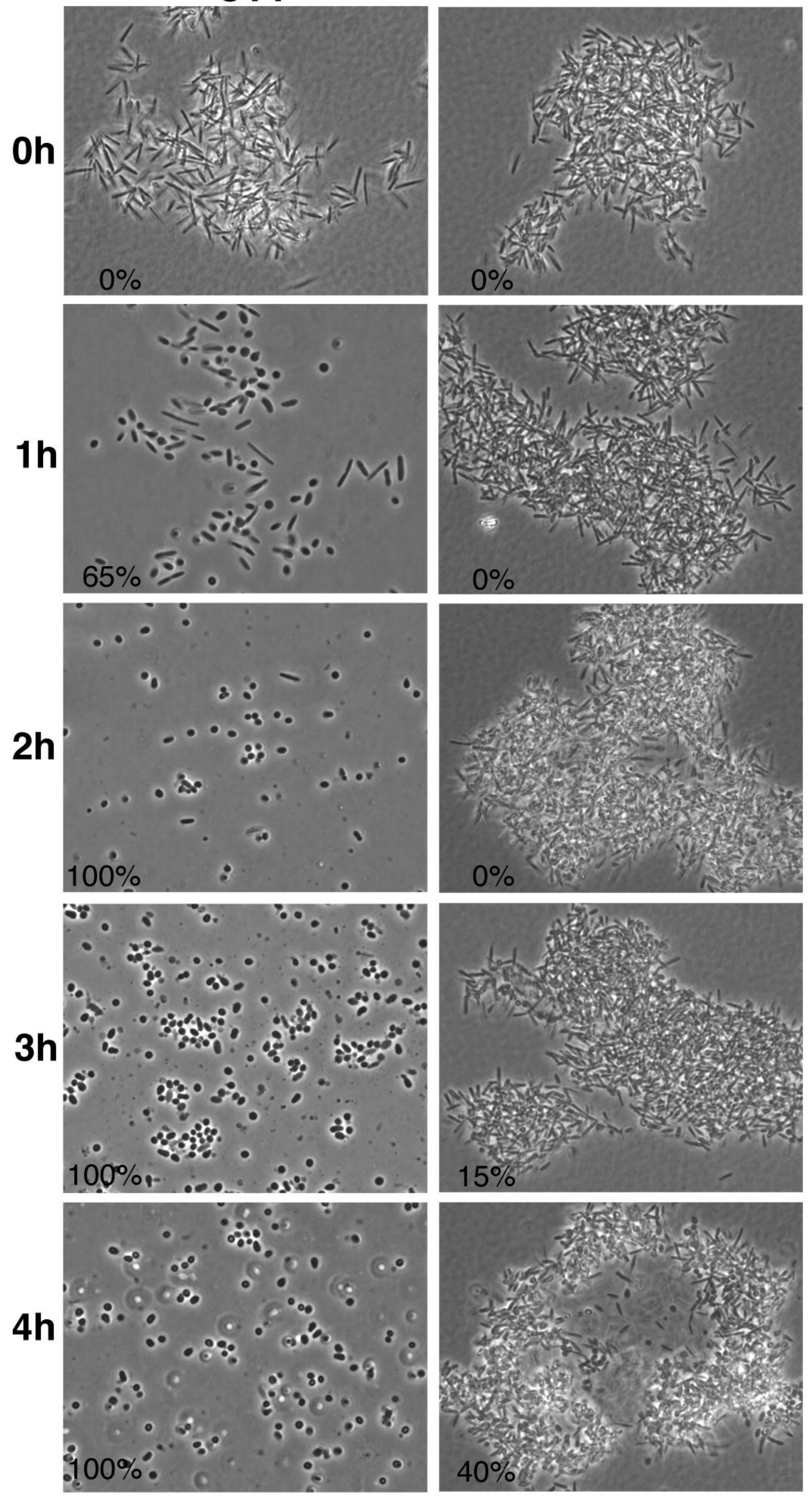